\title{
Methemoglobinemia in Two Infants Brought to the Pediatric Emergency Department
}

\author{
๑ Ayşegül Pala,' ๑ Olena Erkun, $\odot$ Öner Özdemir, ${ }^{2}$ ¿ Zahir Şehmusoğlu'
}

\author{
'Department of Pediatrics, Sakarya \\ University Training and Research \\ Hospital, Sakarya, Turkey \\ ${ }^{2}$ Department of Pediatric \\ Immunology and Allergy Medicine, \\ Sakarya University Faculty of \\ Medicine, Sakarya, Turkey \\ Submitted: 12.11.2019 \\ Accepted: 17.05.2020 \\ Correspondence: Ayşegül Pala, \\ Sakarya Üniversitesi Eğitim ve \\ Araştırma Hastanesi, Çocuk Sağlığı \\ ve Hastalıkları Anabilim Dalı, \\ Sakarya, Turkey \\ E-mail: aysegul.pala.21@gmail.com

口rsa \\ Keywords: Cyanosis; \\ methemoglobinemia; \\ methylene blue; prilocaine.

\begin{abstract}
Methemoglobinemia is a complication that develops when ferrous hemoglobin is oxidized to a ferric state. It may be congenital due to structural hemoglobin defects or acquired through causes such as exposure to local anesthetic drugs or intake of toxins. Methemoglobinemia is characterized by cyanosis when the blood level exceeds $10 \%$, and at higher levels it may cause tissue hypoxemia, coma, cardiovascular collapse, or even death. The primary mechanism used to reduce the methemoglobin level in the body is the nicotinamide adenine dinucleotide phosphate-cytochrome b5 reductase pathway. This case report is a presentation of the diagnosis and treatment of prilocaine-induced methemoglobinemia in 2 recently circumcised infants admitted to the pediatric emergency department.
\end{abstract}

\section{INTRODUCTION}

Methemoglobin is formed as a result of the ferrous iron $(\mathrm{Fe} 2+)$ in hemoglobin $(\mathrm{Hb})$ turning into ferric $(\mathrm{Fe} 3+)$ state. [l] With the increased methemoglobin level, sufficient oxygen cannot be transported to the tissues and methemoglobinemia, characterized by cyanosis, develops. The methemoglobin level in healthy people does not exceed $1.5 \%$, but values above $10 \%$ cause a leftward shift in the oxygen dissociation curve and show signs of low saturation with cyanosis. ${ }^{[2]}$ An acute increase in methemoglobin level above $70 \%$ may cause multiple organ failure resulting in death. ${ }^{[3]}$

Methemoglobinemia may develop from congenital or acquired etiologies. While congenital methemoglobinemia is caused by structural hemoglobin disorders and deficiencies in methemoglobin reduction enzymes, acquired methemoglobinemia may develop due to administration of local anesthetic drugs with oxidant properties, chemical substances and food intake, as well as some diseases seen in infancy. ${ }^{[4]}$
Prilocaine is one of the local anesthetic drugs that cause acquired methemoglobinemia. Patients may develop symptoms such as pale skin, gray or blue lips and nail beds, dizziness, headache, tachycardia, fatigue, and shortness of breath. Oxygen support, ascorbic acid, intravenous methylene blue and, in severe cases, blood transfusion are used as treatment modalities. ${ }^{[5]}$

In this case report, the diagnosis of methemoglobinemia and current treatments in two babies who were admitted to the pediatric emergency service with an interval of one week with complaints of restlessness, absence of suckling, development of central cyanosis after the use of local anesthetic drugs during the circumcision procedure were mentioned, and current treatments are explained in the light of the literature.

\section{CASE REPORT}

Case I- One and a half month- old baby boy was brought to the pediatric emergency service of our hospital due to signs of bruising on his body, respiratory distress, ab- 


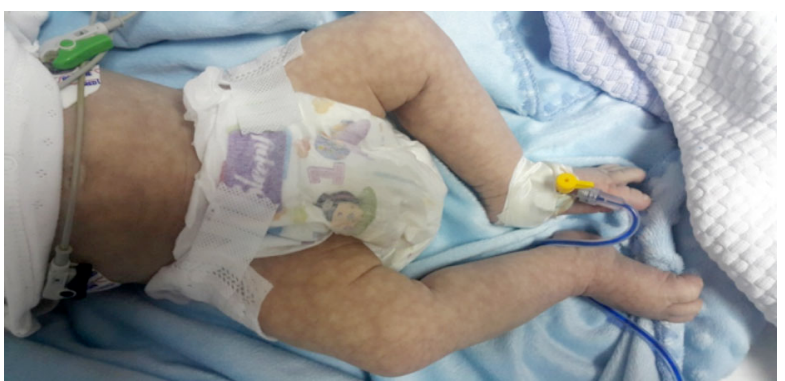

Figure 1. The appearance of 'cutis marmaratus' in our Case 1.

sence of suckling, and restlessness. In the anamnesis, it was learned that approximately 5 hours ago, circumcision was performed in an external center. The patient's perinatal and postnatal history and family history were unremarkable, his preoperative physical examination was natural, and $2 \mathrm{mg} / \mathrm{kg}$ prilocaine (Citanest $2 \%$ vial) was administered as a local anesthetic for the circumcision procedure. His physical examination findings were as follows:, moderately well general condition; body temperature: $36.9^{\circ} \mathrm{C}$; body weight: $4.500 \mathrm{~g}\left(75^{\text {th }}\right.$ percentile); height: $56 \mathrm{~cm}\left(50^{\text {th }}\right.$ percentile): head circumference: $38 \mathrm{~cm}$ ( $50^{\text {th }}$ percentile); blood pressure: $88 / 52 \mathrm{~mm} \mathrm{Hg}$; maximum heart rate (MHR): 168/ min; rhythmic heart rates; no murmur, bilaterally normal lung sounds; respiratory rate: $62 / \mathrm{min}$; $\mathrm{SPO}_{2}$ : $94 \%$; cyanotic, skin and mucosa; and cutis marmaratus-like appearance (Fig. I).

The patient, whose other systemic examinations were within normal, was given 100\% oxygen therapy. Capillary blood gas values were as follows:), $\mathrm{pH}: 7.42 \mathrm{I} ; \mathrm{pCO}_{2}: 36$ $\mathrm{mmHg} ; \mathrm{pO}_{2}: 31.6 \mathrm{mmHg}$, and methemoglobin: $32.6 \%$. It was thought that methemoglobinemia might develop due to the use of local anesthetic, since no underlying cardiac and respiratory pathology was found. With the diagnosis of acute methemoglobinemia, methylene blue $(1 \mathrm{mg} / \mathrm{kg}$ IV/dose); ascorbic acid (55 mg/kg IV/dose) and fluid supplements were given. Results of hemogram, biochemical examinations and chest radiography of the patient were within normal limits. His ECG was compatible with sinus tachycardia. After the treatment, the level of methemoglobin decreased to $3.1 \%$ at the $2^{\text {nd }}$ hour and to $0.8 \%$ at the $12^{\text {th }}$ hour, and his cyanosis regressed. The patient's glucose 6 phosphate dehydrogenase (G6PD) value (19.89 $\mathrm{u} / \mathrm{g}$ ) was within the normal range.

Case 2- A 2-month-old baby boy was brought to the pediatric emergency department due to complaints such as signs of bruising on his body, respiratory distress, absence of suckling, restlessness and persistent crying. In the anamnesis, it was learned that he was circumcised at home about 2 hours ago. In the perinatal and postnatal history, it was learned that the baby who was born at term received phototherapy for 2 days due to hyperbilirubinemia. His family history, and preoperative physical examination findings were unremarkable. It was learned that prilocaine at a dose of $2 \mathrm{mg} / \mathrm{kg}$ (Citanest 2\% vial) was used as a local anesthetic for the circumcision procedure. After the circumcision, skin discoloration was noticed on his body, so

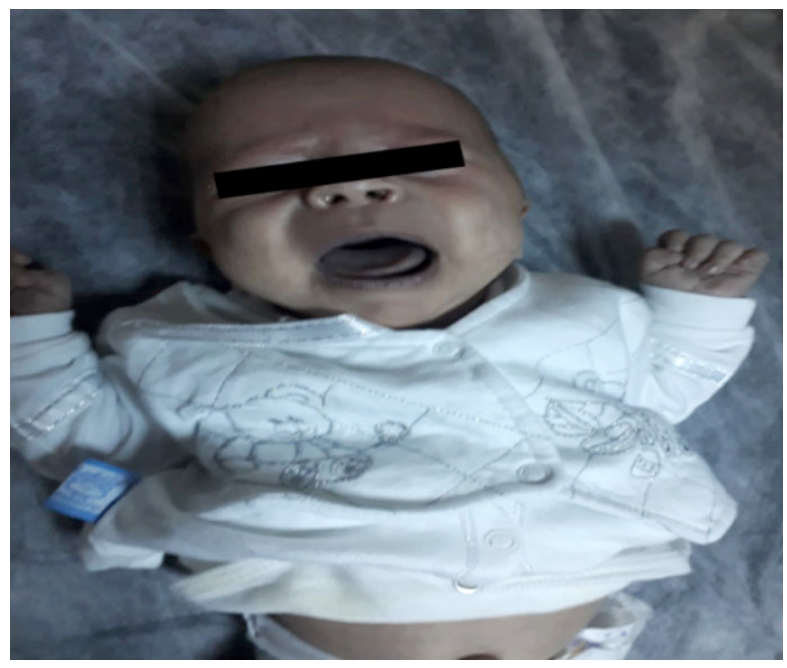

Figure 2. Our restless Case 2 with central cyanosis.

he was brought to the emergency room. In the physical examination, his general condition was moderately well. But he was restless, and appeared to have central cyanosis (Fig. 2), while other systemic examination findings were within normal limits.

At room air $\mathrm{SPO}_{2}$ was $92 \%$. Other parameters were as follows: heart rate: $164 / \mathrm{min}$, body temperature: $37^{\circ} \mathrm{C}$. $\mathrm{pH}$ of blood gas: 7.37; $\mathrm{pCO}_{2}: 39.6 \mathrm{mmHg} ; \mathrm{pO}_{2}: 40.7 \mathrm{mmHg}$; $\mathrm{HCO}_{3}: 22.8 \mathrm{mmol} / \mathrm{L}$; base deficit: $-1.7 \mathrm{mmol} / \mathrm{L} ; \mathrm{Na}: 133$ $\mathrm{mmol} / \mathrm{L}$; fasting blood glucose: $96 \mathrm{mg} / \mathrm{dL}$, and methemoglobin: $39 \%$. The patient was diagnosed with methemoglobinemia based on the use of local anesthetic before the circumcision procedure and lack of any underlying cardiac and respiratory distress. Oxygen was delivered to the patient at a dose of 8-10 It $/ \mathrm{min}$ using a hood. Besides, methylene blue (IV I mg/kg/dose), ascorbic acid (50 mg/ $\mathrm{kg}$ ) and fluid supplements were administered. During follow-up the bruising signs on the skin of the patient disappeared. His $\mathrm{SPO}_{2}(95 \%)$, heart rate $(136 / \mathrm{min})$ improved and his methemoglobinemia decreased to $3.8 \%$. Glucose 6 phosphate dehydrogenase (G6PD) value was within nor$\mathrm{mal}$ (19.5 u/g) range.

\section{DISCUSSION}

The ferrous form of iron $(\mathrm{Fe} 2+)$ in the hemoglobin molecule turns into ferric form $(\mathrm{Fe} 3+)$ as a result of oxidation and methemoglobin is formed. Methemoglobin is normally below 1.5\%, but if it rises, methemoglobinemia develops. Methemoglobinemia can be congenital or acquired. Drugs such as sulfonamides, local anesthetics (benzocaine, lidocaine, prilocaine), phenytoin and nitrate-containing vegetables are the most common causes of acquired methemoglobinemia. ${ }^{[6]}$ Excess methemoglobin formed in the blood is destroyed by nicotinamide adenine dinucleotide (NADH) -cytochrome b5 reductase (main pathway) and nicotinamide adenine dinucleotide phosphate (NADPH) methemoglobin reductase (secondary pathway) erythrocyte enzyme systems (Fig. 3). 


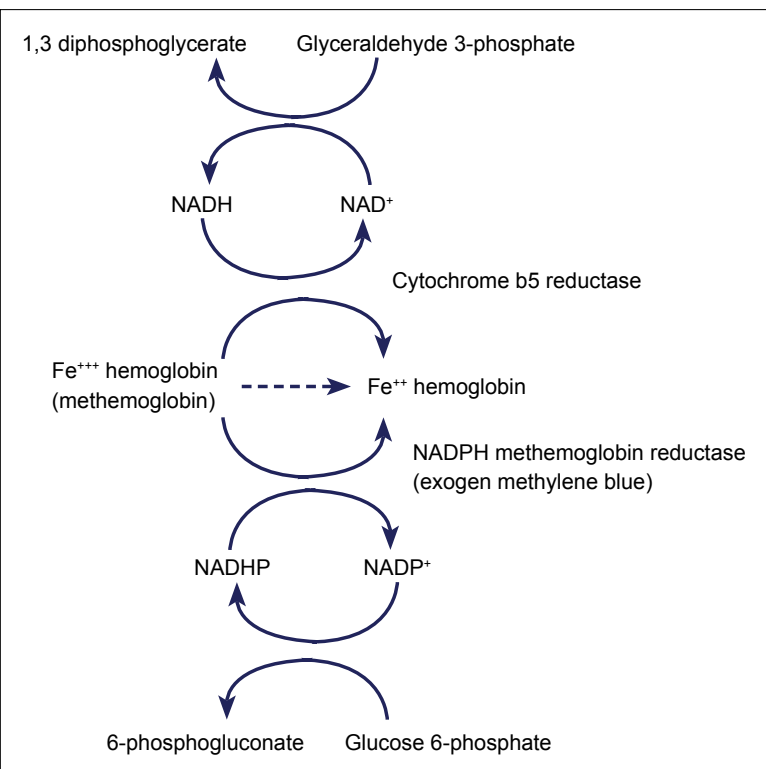

Figure 3. Metabolic pathways for the reduction of methemoglobin.

Prilocaine is widely used as a local anesthetic by injection (Citanest) and in the form of prilocaine-lidocaine (EMLA) cream. Its therapeutic doses are I, and $2 \mathrm{mg} / \mathrm{kg}$. As a local anesthetic agent, prilocaine does not cause cyanosis at therapeutic doses, but some cases of cyanosis have been reported in the literature. ${ }^{[7]}$ Although prilocaine had been used in therapeutic dose in our cases, methemoglobinemia due to prilocaine developed.

Increased levels of methemoglobinemia causes a left shift of the hemoglobin oxygen dissociation curve, acute and severe functional anemia, hypoxemia, and thus central cyanosis and lactic acidosis develop. If the methemoglobin level is below $20 \%$, supportive treatment and observation can be given, if it is above $30 \%$, low doses of methylene blue treatment can be prescribed. Hyperbaric oxygen and blood exchange transfusion may be required if the methemoglobin level is above $70 \%{ }^{\left[{ }^{8]}\right.}$ In our Case I, the methemoglobin level was $32.6 \%$ and in our Case 2, the methemoglobin level was $39.6 \%$. Two hours after the treatment of both patients with methylene blue and ascorbic acid, cyanosis regressed.

Unlike the methylene blue cytochrome b5 reductase enzyme, NADPH lowers the level of methemoglobin with the methemoglobin reductase enzyme using the cofactor NADPH. Thus, while normally in the absence of electron carriers in red blood cells, methylene blue (redox dye) activates this pathway as an electron acceptor (Fig. I). In glucose- 6 phosphate dehydrogenase deficiency, if methylene blue uses NADPH in the normal hexose monophosphate pathway, then it increases methemoglobinemia and may cause hemolytic anemia. ${ }^{[9]}$ In G6PD enzyme deficiency, methylene blue increases methemoglobinemia and causes dyspnea, cyanosis, and hemolytic anemia. Since laboratory tests for G6PD enzyme deficiency were not routinely studied and the result was obtained days later, intravenous methylene blue and then ascorbic acid were administered to our two patients who were brought to the emergency room.

An alternative treatment for methemoglobinemia is vitamin $C$ (ascorbic acid) supplementation, but there is no definitive data on the dosage, efficacy, or renal side effects of vitamin C. It has been proven that vitamin $\mathrm{C}$, by using a non-enzymatic method in treatment, directly reduces the level of methemoglobin and regresses cyanosis with its antioxidant properties. ${ }^{[10]}$ In order to increase the plasma concentration, vitamin $\mathrm{C}$ should be given intravenously at a high dose. Intravenous methylene blue is the first-line treatment for patients without G6PD deficiency, however. It is important to use ascorbic acid in congenital cases due to its antioxidant properties.

In conclusion, prilocaine and other drugs used as local anesthetics are the causes of acquired methemoglobinemia in newborns and young children. Although it is necessary to consider, and exclude pulmonary causes and congenital heart diseases in children with cyanosis, methemoglobinemia should also be kept in mind. Methemoglobinemia should be considered among the rcausative factors, especially in patients who develop central cyanosis after the use of local anesthetics in their medical history.

\section{Informed Consent}

Written informed consent was obtained from the patient for the publication of the case report and the accompanying images.

Peer-review

Internally peer-reviewed.

Concept: A.P., Ö.Ö., Z.Ş.; Design: A.P., O.E., Ö.Ö.; Supervision: Ö.Ö.; Fundings: A.P., O.E., Z.Ş.; Materials: A.P., O.E., Ö.Ö., Z.Ş.; Data: A.P., O.E., Ö.Ö., Z.Ş.; Analysis: A.P., O.E., Ö.Ö., Z.Ş.; Literature search: A.P., Ö.Ö.; Writing: A.P., Ö.Ö.;Critical revision: Ö.Ö.

Conflict of Interest

None declared.

\section{REFERENCES}

1. Caner İ, Ziraatçı Ö, Taştekin A. Methemoglobinemia due to prilocaine which treated with oral methylene blue. Çocuk Hast Derg 2011;5:172-6.

2. Mansouri A. Methemoglobinemia. Am J Med Sci 1985;289:200-9.

3. Hjelt K, Lund JT, Scherling B, Bendixen S, Lundstrøm K, Støvring S, et al. Methaemoglobinaemia among neonates in a neonatal intensive care unit. Acta Paediatr 1995;84:365-70.

4. Svecova D, Bohmer D. Congenital and acquired methemoglobinemia and its therapy. Cas Lek Cesk 1988;137:168-70.

5. Kara A, Yiğit S, Aygun C. Toxic methemoglobinemia after injection of prilocaine in a newborn case report. Turk J Pediatr 1998;40:589-92.

6. Coleman MD, Coleman NA. Drug induced methemoglobinemia. Drug Safety 1996;14:394-405.

7. Shamriz O, Cohen-Glickman I, Reif S, Shteyer E. Methemoglobinemia induced by lidocaine-prilocaine cream. Isr Med Assoc J 2014;16:250-4. 
8. Wright RO, Lewander WJ, Woolf AD. Methemoglo-binemia: Etiology, Pharmacology, and Clinical Management. Ann Emerg Med 1999;34:646-6.1.

9. Aydoğan M, Gedikbaşı T, Türker G. Prilokaine bağlı toksik methe- moglobinemide intravenöz askorbik asit kullanımı. Çocuk Sağlı̆̆ ve Hastalıkları Dergisi 2005;48:65-8.

10. Prchal JT, Gregg XT. Red cell enzymes. Hematology Am Soc Hematol Educ Program 2005:19-23.

\section{Çocuk Acil Servisine Getirilen Iki Bebekte Methemoglobinemi}

Kanda ferröz değerliğinde bulunan hemoglobinin okside olup ferrik duruma geçmesine methemoglobinemi denir. Doğuştan yapısal hemoglobin defektleri veya lokal anestezik ilaçlar, kimyasal madde ve gıda alımı gibi edinsel sebeplerden ötürü gelişebilir. Methemoglobinemi seviyesi \% I0'u geçtiği durumlarda siyanoz ile karakterize iken, daha yüksek durumlarda doku hipoksemisi, koma, kardiyovasküler kollaps ve hatta ölüme bile neden olabilir. Bu seviyeyi vücutta düşüren ana mekanizma nikotinamid adenin dinükleotid (NADH)-sitokrom b5 redüktaz yolağıdır. Bu olgu sunumuzda, çocuk acil servisimize farklı zamanlarda başvuran iki bebeğin sünnet işleminde prilokaine bağı gelişen methemoglobineminin tanı ve tedavisi anlatılmaktadır.

Anahtar Sözcükler: Methemoglobinemi; metilen mavisi; prilokain; siyanoz. 